\title{
How Transnational Migrants Integrate: The Case of Moldovans Living in Czechia and Italy*
}

\author{
EVA JANSKÁ, JIŘÍ HASMAN and ZDENĚK ČERMÁK** \\ Faculty of Science, Charles University, Prague
}

\begin{abstract}
This article examines whether the social, cultural, or economic dimensions of integration into a receiving society have the effect of intensifying or weakening transnational ties to a migrant's country of origin. The article is based on an analysis of unique data gathered in a questionnaire survey conducted among 409 Moldovan migrants living in Italy and Czechia and resident there for more than one year. Transnational and integration indices were constructed in order to investigate the relationships between selected characteristics of the respondents. The analysis reveals that greater socio-cultural integration is accompanied by weaker transnational practices, where key roles are played by the length of stay and age upon arrival. This is found to apply to Moldovans in both countries, although a slightly more positive relationship is observed between Italian Moldovans' economic integration and transnationalism, suggesting that economic resources facilitate the maintenance and development of cross-border networks.
\end{abstract}

Keywords: transnationalism, integration, Moldovans, Italy, Czechia

Sociologický časopis/Czech Sociological Review, 2021, Vol. 57, No. 3: 267-292

https://doi.org/10.13060/csr.2020.011

\section{Introduction}

Since the early 1990s, several researchers have focused on the increasing intensity and scale of the circular mobility of persons, goods, and information triggered by international migration [Düvell and Vogel 2006; Vertovec 2010]. Different forms of contact with family members and others in an immigrant's country of origin has led to the study of not only what happens in the country of destination, but also what interconnections with the country of origin remain. In this context, a number of studies have focused on transnational migrant typologies [e.g. Da-

\footnotetext{
* Disclosure statement: No potential conflict of interest was reported by the authors. Funding: Results presented in this article were supported by the Czech Science Foundation project no. P404/16-22194S and Charles University [UNCE/HUM 018].

** Direct all correspondence to: Eva Janská, Department of Social Geography and Regional Development, Faculty of Science, Charles University in Prague, e-mail: ejanska@natur. cuni.cz.
} 
hinden 2010; Engbersen et al. 2013] to explain the migratory behaviour of migrants.

Hand in hand with this 'new' line of research has been the question of migrant integration, which adopts a different perspective centred on the challenges that immigration poses for individual societies [Entzinger and Biezefeld 2003; Snel, Engbersen and Leerkes 2006; Vertovec 2007; Erdal 2013]. While much of the research from the last century addressed the ways in which migrants adapted to new societies and contexts [Portes and Rumbaut 1996; Alba and Nee 2003], early discussions on the transnational context have presented an alternative form of immigrant adaptation [e.g. Itzigsohn et al. 1999; Faist 2000; Cela, Fokkema and Ambrosetti 2013; Morad and Della Puppa 2019]. The new paradigm has argued that immigrants redefine, but do not break, their links to their country of origin [Basch, Schiller and Szanton Blanc 1994; Levitt 2001; Portes, Guarnizo and Landolt 1999; Vertovec 1999; Faist 2000]. Many migrants develop and maintain strong modes of community cohesion, both at home and elsewhere among the diaspora, although this does not mean they are not integrating into their places of settlement. According to Vertovec [2010], becoming more transnational does not mean a person is less integrated, and less integrated people do not necessarily display stronger transnational patterns.

Empirical research has demonstrated the complexity of the relationships between modes of transnationalism and integration [Itzigsohn and Saucedo 2002; Guarnizo, Portes and Haller 2003; Morawska 2003; Portes 2003; Vertovec 2010; Erdal 2013] that can be explained in various ways. For example, economic transnational practices, such as remittances, can, on the one hand, be positively associated with and accelerate the long-term integration of immigrants [Portes, Haller and Guarnizo 2002]; on the other hand, this can be a limiting factor in other dimensions of integration [Vertovec 2010]. Less is known, however, about how different types of transnational practices are interconnected with the social, cultural, and economic integration of immigrants. Moreover, there has been little direct research into what drives people to engage in transnational practices.

This article is based on a study that sought to expand our knowledge of immigrant integration through an exploration and analysis of their modes of transnational practices and participation. Although immigrant integration and transnational processes may depend on the context of the destination country, most studies focus on one destination country only. To include the important role of context, we deployed our survey in two countries - Italy and Czechia. These countries have relatively recently been transformed from emigration to immigration countries, whilst at the same time they offer different migration conditions given their disparate political and economic development over the second half of the 20th century. For the study, we selected the Moldovan immigrant community, which has exhibited a high degree of transnationalisation, indicated by economic factors, a high emigration rate, the large share of GDP made up of remittances (the largest share in Europe), and geographical proximity within the European 
space. Because Moldovans in Italy can take advantage of a smaller difference between their language and the destination country's language and a generally longer length of stay (which definitely plays a role in the integration process; e.g. Faist [2000]) than in Czechia, it can also be expected that their integration outcomes will differ.

Our research questions therefore were: How do the transnational practices and the integration of Moldovans differ between Czechia and Italy and how could their mode of transnational network explain their social and economic integration (i.e. what is the relation between immigrants' transnational activities and ties to their country of origin on the one hand, and their integration into the receiving country on the other?

The first part of the paper provides a brief account of the background to Moldovan migration, with reference to Czechia and Italy as destination countries. We then provide a theoretical framework in which we discuss the different transnational typologies of labour migrants to Western countries and their potential forms of integration. Based on this, we constructed three indices comprising the variables discussed (one transnationality variable and two integration variables) that formed part of our analysis.

We then present the descriptive statistics on the basic characteristics of the respondents, analysing different patterns of migration and integration based on Czech and Italian data and determining five 'ideal' groups of transnational migrants. We then analyse and explain how the degree of integration depends on the mode of transnationalism and show which types of labour migrant are related to the different patterns of integration. The final section situates our findings in the context of the wider debate on transnationalism and integration.

\section{The background to Moldovan migration}

Moldova is the poorest country in Europe (EU), ${ }^{1}$ with a per capita GDP that is about one-third of that of Italy or Czechia. Its poor socio-economic situation is the result of its long-term development on the periphery of Europe and a prevailingly agricultural economy. In addition, its loss of access to the former Soviet market after the collapse of the Soviet Union and the separation of the Dniester Republic have had a negative impact on Moldova's economy and political situation. Because of this, after 1990 Moldova became a high-emigration country. In 2013 the number of long-term emigrants was estimated at 411 000. (i.e. $12.4 \%$ of the total population), with short-term seasonal migration amounting to around 100000 people [de Zwager and Sintov 2014]. The largest number of Moldovan migrants are in Russia (over 50\% of all emigrants) and in the EU, with most of them traditionally centred in Mediterranean countries such as Italy, Portugal, Spain,

\footnotetext{
${ }^{1}$ Per capita GDP is USD 5698 [World Bank 2018].
} 
Table 1. Moldovan immigrants in Czechia (CR) and Italy in 2017

\begin{tabular}{|c|c|c|c|}
\hline & & CR & Italy \\
\hline \multicolumn{2}{|c|}{ Total number of Moldovans } & 5459 & 130000 \\
\hline \multicolumn{2}{|c|}{ Share of Moldovans out of all immigrants } & $1.09 \%$ & $3.50 \%$ \\
\hline \multicolumn{2}{|c|}{ Share of males } & $56 \%$ & $33 \%$ \\
\hline \multicolumn{2}{|c|}{ Age group $50+$} & $18 \%$ & $23 \%$ \\
\hline \multicolumn{2}{|c|}{ Permanent residence } & $71 \%$ & $71 \%$ \\
\hline \multirow{5}{*}{$\begin{array}{l}\text { Employment } \\
\text { by economic } \\
\text { sector }\end{array}$} & domestic and personal services & $16 \%$ & $48 \%$ \\
\hline & industry and construction & $46 \%$ & $19 \%$ \\
\hline & transport and production services & $16 \%$ & $15 \%$ \\
\hline & commerce & $12 \%$ & $15 \%$ \\
\hline & agriculture & $11 \%$ & $3 \%$ \\
\hline
\end{tabular}

Source: Drbohlav et al. [2017].

and Greece. This is mainly because EU countries became easily accessible when the visa-free regime came into effect, as many Moldovans were able to obtain Romanian passports, and Romania has been part of the EU since 2007. It is clear that this significant rate of emigration was linked to remittances, with Moldova ranking among the countries with the highest share of remittances in their GDP (24\% in 2015; World Bank [2018]). Moreover, social remittances may also play an important role in accelerating socio-economic transformation processes [Cingolani and Vietti 2019].

The selected destination countries (Italy and Czechia) have features in common and features that differ and were chosen to offer an interesting picture of two EU countries with different political, cultural, geographical, and economic contexts (see Table 1). The Moldovan community in Czechia is the largest among the post-socialist Central European countries [United Nations 2015], while Italy has the overall largest group of Moldovans after Russia. Moldovan migration to Czechia and Italy shares further features, such as the type of immigrant residence and greater employment in the secondary labour market sectors typical for low-skilled labour. On the other hand, the differences between the two countries include employment in Italy being predominantly in domestic services (typical for women), whilst in Czechia men typically find work in the construction and industry sectors. We should also mention that the conditions in Italy may be more favourable for Moldovan immigrants than they are in Czechia. First, Italian and Moldovan are Romance languages, which makes Italian much easier for Moldovans to learn than Czech. Second, Italy has a much higher hourly wage for labour than Czechia does (EUR 28.8 compared to EUR 13.5, respectively, in 2019; Eurostat [2020]), which could affect the outcome of both countries when comparing 
the degree of transnationalism and economic integration (and for this reason we have excluded this variable; see below). Third, the length of stay is longer in Italy than in Czechia, which is a potential indicator of a higher degree of socio-cultural integration in Italy.

Based on this knowledge, we would expect different degrees of integration and transnational behaviour to be exhibited by Czech and Italian Moldovans. The question, however, is: how much do their transnational behaviours influence the degree of integration, particularly in economic and socio-cultural terms [e.g. Penninx and Garcés-Mascareñas 2016]?

\section{Conceptual framework}

In this section, we introduce two concepts to explain the relationship between contemporary transnational migratory processes and the socio-cultural and economic integration of third-country nationals (Moldovans) in the territory of the EU.

\section{Transnational migratory processes}

The relationship between migrants and their country of origin has been linked to many different processes and problems [see Glick Schiller, Basch and Szanton Blanc 1992; Vertovec 2010; Baldassar and Merla 2014]. Several studies on the transnational behaviour of migrants have relied predominantly on small-scale, qualitative data or ethno-surveys. Such studies have often been based on a limited number of interviews and are characterised by the construction of typologies [Düvell and Vogel 2006; Eade, Drinkwater and Garapich 2006; Grabowska and Okolski 2009; Dahinden 2010; Trevena 2013; Janská, Pauknerová and Koropecká 2017; Morad and Della Puppa 2019], although there have also been some quantitative surveys [e.g. Engbersen et al. 2013] similar to ours. Both approaches have been used to develop typologies alongside data analysis as an effective means of sparking the theoretical imagination during the research process.

Transnational processes encompass a wide variety of activities, ranging from individual links to those with transnational institutions. Faist [2000] distinguished three different levels of the institutionalisation of transnational communities: (1) transnational kinship groups based on the linkages and obligations among family and household members or close friends; (2) transnational circuits, such as trading or business networks, or other forms of recurrent transnational activities; and (3) transnational communities that imply the emergence of public institutionalised practices involving the mobilisation of collective representations [Itzigsohn and Saucedo 2002]. We have developed the first level of Faist's [2000] classification by assuming that the issue of time (duration of residence in the host society) is a key feature for understanding the evolution of transnational 
behaviour towards integration at the individual migrant level. The underlying assumption is a positive relationship between duration of residence and integration [Faist 2000].

While Engbersen et al. [2013], among others [Düvell and Vogel 2006; Eade et al. 2006; Grabowska and Okolski 2009; Trevena 2013], focused on Central and Eastern European labour migrants, Dahinden [2010] and Janská, Pauknerová and Koropecká [2017] also considered migrants from third countries, such as Ukrainians, Albanians, and Armenians. These studies attempted to map out the diversity of modern migration patterns. Dahinden [2010] identified four basic transnational types based on the intensity of the migratory relations between the country of origin and the destination country and on connections with a local community in the destination country. While she emphasised important differences between these four 'ideal' types of transnational groups, she also acknowledged the dynamic nature of the development of transnationality, as influenced by the migratory policies of EU countries and, ultimately, by the EU itself. Janksá, Pauknerová and Koropecká [2017] added remittances, marital status, gender, mobility, and the location of immigrants into their model, creating a typology in which the specifics of transnational processes could be assessed. They argued that the different behaviours exhibited by transnational migrants is a reflection of their socio-demographic characteristics (e.g. family status, education, or number of children), which could change over time.

Engbersen et al. [2013] also added variables relating to integration into their model, illustrating how constructive two dimensions can be in contemporary migration typologies. The first related to socio-cultural, socio-economic, and demographic factors, such as a command of the national language, contact with the native population, a strong or weak labour-market position, and cohabiting with a partner and children in the destination country. The second dimension was the degree to which migrants remain attached to their country of origin. The result identified four ideal types of labour migrants.

The identities, activities, and connections linking migrants with their communities in their country of origin are unprecedented, but they are not of a level or type similar to transnational engagement [Vertovec 2010]. Much of this is largely conditioned by a range of factors such as migration channel, legal and marital status, migration history, economic means, political circumstances in the country of origin, or remittances. For instance, Sana [2005] showed that the prominent transnational practice of remitting money correlated with renting a home, a lack of citizenship, and a lack of language knowledge, all of which are also evidence of limited migrant integration.

The relationship between remittances, return migration, and length of stay has already been analysed by Constant and Massey [2002], who used the new economy of labour migration and neoclassical concepts to determine the variables that are linked to who settles permanently in order to maximise earnings and who settles temporarily to achieve a particular earnings target and intend to eventually return home. 
Snel, Engbersen and Leekes [2006] also observed that social position (education level, labour market participation) does not play a significant role in transnational activities, which could occur between both migrants with good social standing in the host society and those who are more marginalised. On this basis, we formulated our key hypothesis, H1: If there are different types of transnational migrants, there will also be differences between those same nationals (Moldovans) in different EU countries (Czechia vs Italy) in terms of their transnational behaviours and integration.

Despite the large number of studies that have investigated the transnational lives of migrants, most were conducted on the United States. Consequently, the transnational behaviour of migrants in Europe has been less documented, particularly in post-communist countries. In addition, as far as European studies are concerned, attention has almost exclusively been focused on longer-established migration groups (e.g. Moroccans and Turks) rather than on more recent groups, like those from Central and Eastern Europe [Cela et al. 2013]. Creating new typologies of transnational migrants will allow us to better explain new immigrant practices in different European countries in terms of economic and socio-cultural integration [e.g. Portes et al. 1999].

\section{Socio-cultural and economic integration}

Generally, the term 'integration' refers to the process of settlement, interaction with the host society, and the social change that follows immigration. As soon as immigrants arrive in a host society, they must find a home, a job and income, schools for their children, and access to health facilities. They must interact with other individuals and groups, and get to know and use the institutions of the host society [Penninx and Garcés-Mascareñas 2016].

Classical assimilation theory argues that the longer migrants remain in the host society, the more they will be integrated and the less they will remain connected to their home country [Gordon 1964; Alba and Nee 1997]. Such studies usually show that greater integration yields durations of stay that are longer than were intended. This paradigm for the analysis of immigration assumes a break with networks in the home country and engagement in the process of integration, with the degree of loyalty towards the country of origin (or that of the parents) becoming the litmus test of successful integration [Mügge in Penninx and Garcés-Mascareñas 2016]. In this sense, Engbersen et al. [2013] demonstrated that there is no strong connection between attachment to the homeland and integration, although integration can go hand in hand with either strong or weak forms of transnationalism - and the idea of 'integration here' and 'development there' plays an important role in the relationship between transnationalism and integration.

Immigrants can be incorporated into the host society at different levels and in different dimensions [e.g. Entzinger and Biezefeld 2003] and an understanding 
of the determinants concerning migrant integration is important in an analysis of the particular factors that explain return behaviour [e.g. Dustmann 1996; Constant and Massey 2002]. Apart from political involvement, there are degrees of sociocultural and economic integration that play an important role in the integration process and the transnational activities of immigrants. While the socio-cultural integration of immigrants can be described in terms of, for example, host-country language skills and ties with the indigenous population, economic integration is related to a person's position in the foreign labour market. Economic integration is generally discussed in terms of the earnings parity between immigrants and natives with similar characteristics and the rise in immigrant income over time. Moreover, many researchers have stressed that immigrant entrepreneurs engage in different business activities from native-born persons, owing to the particularities of their human and cultural capital (differences in education, profession, cultural norms, beliefs, and values derived from the person's background culture; Kushnirovich [2015]).

Relevant studies have tended to demonstrate that migrants who are economically well integrated into the host country are more likely to maintain meaningful transnational engagement with their origin-country society, including sending remittances and engaging in other actions with positive developmental outcomes, such as business investments. On the other hand, migrants who are socio-culturally well integrated are more likely to become detached from their home country, therefore becoming less actively involved in transnational activities that might lead to development. King and Collyer [2016] argued that this contrasting correlation - positive for economic integration, transnationalism, and development and negative for impact of socio-cultural integration - seems to hold for both first- and second-generation migrants. A survey of more than $3000 \mathrm{im}-$ migrants in Norway and an ethnographic study of Somalis in the UK [Hammond 2013] confirmed that economic integration is decisive for sending remittances. On the other hand, Portes, Haller and Guarnizo [2002] found that economic transnational practices are positively associated with and accelerate rather than slow long-term integration, and vice versa.

Can transnationalism and integration thus be mutually beneficial, or is it a zero-sum relationship? Research on the relationship between migrant transnationalism and integration has resulted in mixed findings rather than evidence that conclusively points in any particular direction. Some studies have supported the idea that integration and transnational ties are not necessarily substitutes but can be complementary, particularly in the case of economic integration [Itzigsohn and Saucedo 2002; Guarnizo, Portes and Haller 2003; Sana 2005; Van Dalen, Groenewold and Fokkema 2005; Fokkema et al. 2012]. Other studies have disagreed with the assumed positive relationship between migrant integration and transnationalism [Basch, Glick Schiller and Szanton Blanc 1994; Portes 1997]. Itzigsohn and Saucedo [2002], in their attempt to analyse integration and transnationalism, identified three forms of transnationalism: (1) the linear form, which 
suggests that, as time passes, integration increases and transnationalism slowly decreases; (2) dependent transnationalism, which implies that time and financial resources are necessary in order to engage in cross-border practices and, thereby, assume a positive relationship between duration of residence, integration, and transnationalism; and (3) reactive, which results from discrimination or a negative experience with integration faced by migrants in the host society. Therefore, a positive relationship between duration of residence, exclusion (negative integration), and transnationalism is assumed.

Thus, we formulated hypothesis $\mathrm{H} 2$, concerning the relationships between duration of residence, integration, and transnationalism: Those who have frequent contact with their home country (e.g. travel home) and a shorter stay of residence in their chosen country are more likely to experience less socio-cultural integration than those who have almost no contact and who have lived longer in the receiving country.

It should be noted that the two hypotheses are complementary in explaining the transnational activities of immigrants together with their modes of integration.

\section{Data and methods}

In this study we used a dataset stemming from a questionnaire survey of two immigrant groups from Moldova $(\mathrm{N}=409),{ }^{2}$ one living in Czechia (in the capital city of Prague and the surrounding region of Central Bohemia; $\mathrm{N}=203$ ) and the second in Italy (the city of Turin and surrounding neighbourhoods; $\mathrm{N}=206$ ) fielded between September 2017 and March 2018. The common mandatory criteria for taking part in the survey were: (1) they have, or had in the past, Moldovan citizenship (including citizenship of the Pridnestrovian Moldavian Republic); (2) they were at least 18 years old; (3) they had lived in Czechia/Italy for at least one year; and (4) they were still in touch with someone in Moldova. In order for the participants to fully understand the questions, the questionnaire was translated into five languages (Moldovan, Italian, Czech, Russian, and English).

In both countries, the snowball method was used to select respondents. This method is particularly useful when a population is hidden and thus difficult to identify [e.g. David and Sutton 2004]. While for Czechia we used the help of Orthodox Church priests, certain Moldovan interpreters used by Moldovan migrants, and selected managers of hostels where Moldovan migrants were known to find accommodation, in Italy we predominantly used cultural associations and parishes of the Orthodox Church. The aim of the sample collection was to gain as wide a spectrum of Moldovan migrants as possible, although the snowball method has clear limitations in terms of obtaining a fully representative

${ }^{2}$ Slightly more than 100 persons (altogether in the two countries) refused to take part in our surveys. 
Table 2. Characteristics of immigrants' transnational behaviour

\begin{tabular}{|c|c|c|c|c|}
\hline Score & 0 & 1 & 2 & 3 \\
\hline $\begin{array}{l}\text { Number of stays abroad } \\
\text { prior to their current stay, } \\
\text { with the answer categories }\end{array}$ & 0 & 1 & 2 & 3 \\
\hline $\begin{array}{l}\text { Frequency with which } \\
\text { remittances are sent }\end{array}$ & Never & $\begin{array}{l}\text { Max. once } \\
\text { per year }\end{array}$ & $1-2$ per year & $\begin{array}{l}\text { More than } \\
\text { twice a year }\end{array}$ \\
\hline $\begin{array}{l}\text { Number of trips to } \\
\text { the country of origin } \\
\text { in the past } 3 \text { years }\end{array}$ & 0 & $1-2$ & 3 & 4 or more \\
\hline $\begin{array}{l}\text { Frequency of contact } \\
\text { with family in Moldova }\end{array}$ & Never & $\begin{array}{l}\text { Less than } \\
\text { once a week }\end{array}$ & Weekly & $\begin{array}{c}\text { Multiple } \\
\text { times a week }\end{array}$ \\
\hline $\begin{array}{l}\text { Frequency of contact } \\
\text { with friends in Moldova }\end{array}$ & Never & $\begin{array}{l}\text { Less than } \\
\text { once a week }\end{array}$ & Weekly & $\begin{array}{c}\text { Multiple } \\
\text { times a week }\end{array}$ \\
\hline
\end{tabular}

sample because it can result in respondents being selected from relatively closed social networks, which thus may result in them having similar characteristics. This was a limitation on the generalisability of the results, which should thus be treated with some caution. We tried to avoid being left with incomplete or missing answers by ensuring that members of the research team were always present when the respondents were filling in their questionnaires and could assist with any problems. We met the respondents in places such as a university campus, a church, coffee bars, restaurants, etc. Filling in the questionnaire took on average 60 minutes, and the respondents were rewarded for their participation (EUR $10^{3}$ ).

The aim of the survey was to gain insight into the transnational migratory behaviour of Moldovans in two different EU countries and into their mode of socio-cultural and economic integration. We also gathered information on basic socio-demographic characteristics, family composition, migration history, work and earnings, financial and social remittances, what remittances were used for, and new experiences connected to migration and related issues.

In accordance with the aims of this work, the empirical section consists of two parts. In the first, k-means cluster analyses were used to create a typology of migrants on the basis of five variables describing their transnational behaviour. All variables were standardised to a four-point ordinal scale from 0 to 3 (Table 2). ${ }^{4}$

\footnotetext{
${ }^{3}$ In addition, mediators who found new respondents in Czechia were rewarded with EUR 10.

${ }^{4}$ Two variables (frequency of remittances and number of visits to Moldova) were originally designed to use a five-point scale, and we used this full scale in the remainder of the study (e.g. Table 3 and the transnationalisation index). For the cluster analysis, however, we had to merge categories to get a four-point scale.
} 
The aim of this study is to identify more general types of migrants; therefore, the data for both countries were analysed and subsequently monitored together. The calculation was repeated for various numbers of clusters, and the most appropriate solution was selected. The resulting clusters were then described on the basis of the variables that indicated the transnational behaviour of migrants, as well as other key characteristics.

In the second part, we examined whether transnationalisation explained socio-cultural and economic integration. Linear regression was used where the dependent variables were both indicators of integration, with the degree of transnationality being the main explanatory variable and the characteristics of the respondents the control variables. Because of the different contexts of migration in the two countries, the Czech and Italian respondents were analysed separately, and the results were then compared. All three indicators were drawn up so that the answers to the individual questions ranged from 0 (lowest rate of transnationality/integration) to 1 (highest rate of transnationality/integration). Subsequently, the response indicators were averaged (from 0 to 1 ).

The degree of transnationality was based on similar characteristics to those used in part one (see Table 2). We proposed that a migrant with strong transnational ties would be more likely to send money home and have frequent contacts with relatives in their country of origin (which does not mean that they were not sufficiently integrated). Therefore, we chose selected characteristics for assessing transnationalism, as well as for constructing the transnational index.

Variables were selected according to the literature (see above) that deals with issues of both transnationalism and integration. Socio-cultural integration was based on: (1) knowledge of the language of the destination country - one of the most important variables in this dimension [e.g. Dustmann 1996; Sana 2005; Engbersen et al. 2013] (categories 0-2) - (2) the time dedicated to certain activities, such as cultural activities with Czech/Italian friends and with Moldovans (categories $0-4$ ), where all the indicators were averaged, and (3) sources from which immigrants obtained information about the host society (Moldovan vs Czech/ Italian friends). Economic integration was then monitored from a limited sample of economically active immigrants using three variables: (1) having a permanent work contract; ${ }^{5}(2)$ integration with the labour market;, ${ }^{6}$ and (3) employment

\footnotetext{
5 The permanent-contract variable was constructed as follows. Immigrants with partial contracts were given a score of 0.5 and those with permanent contracts were given a score of 1 . Retired immigrants who were still employed were given a score of 0.75 because we did not know how large their contracts were. When respondents declared they were unemployed, in both this question and the question about their occupation, their economic integration index was scored as 0 . Some respondents, however, declared they were unemployed but gave conflicting answers about their occupations and job satisfaction, meaning they were (probably) only officially unemployed but worked in the shadow economy. These respondents were given a score of 0 for this item only, while the aggregate index was computed as an average of all three items like other respondents who had stated that they were employed.
} 
satisfaction [e.g. Dustmann 1996; Constant and Massey 2002; Kushnirovich 2015]. We should state that our economic integration index is not ideal, as its construction was limited by the available data. The primary sense of the survey was directed towards transnationalism and social remittances, leaving limited space for questions on the topic of economic integration. The results are presented as standardised regression coefficients, and the coefficient of determination (R2) describes the overall fit of the model.

\section{Descriptive results}

Before introducing the statistical analysis, it is first necessary to introduce the basic characteristics of our respondents. Table 3 shows the average indicators of the key dependent and independent variables according to the country of destination. Despite the fact that our survey was not representative, the basic characteristics (gender, age) of our sample approximate the data for the entire population (Table 1). From the data, it is clear that the Czech Moldovans are more transnational than the Italian Moldovans (according to all four sub-indicators from which the transnationalisation index was constructed), although they are less socio-culturally integrated.

One of the most important indicators of socio-cultural integration is the degree of language knowledge of the destination country. Moldovans in Italy have much better knowledge of the Italian language than Moldovans in Czechia have of Czech, probably due to their being from the same Romance language group, which means both languages are somewhat similar. According to Mosneaga [2012], it takes only 1-2 months for Moldovans to learn Italian. Moreover, the major EU languages, including Italian, are often taught in Moldovan schools [Mosneaga 2012].

The age and gender structure of our respondents also differed. While the Czech Moldovans migrated at an older age and alone (often leaving their partners in Moldova), with an equal distribution among males and females, women predominated among the Italian Moldovans. Furthermore, both respondent groups had a relatively high share of persons with university degrees, although the Italian Moldovans had slightly higher qualification levels.

These data correspond relatively well with the observation that Moldovan migration to Czechia is a recent phenomenon (with a relatively higher share of men with primary-level educational attainment, most of them employed in industry and construction). On the other hand, there is a longer tradition of Mol-

${ }^{6}$ This variable compared the level of qualification required for the current occupation with the level for this job in the mother country and the level of a respondent's education to show whether the professional level of their occupation corresponded with their real qualification level. 
Table 3. Selected characteristics of Moldovan respondents living in Czechia (CR) and Italy

\begin{tabular}{|c|c|c|c|}
\hline & CR & Italy & p-value \\
\hline Index of transnationality & 0.512 & 0.368 & $<0.001$ \\
\hline Number of previous stays abroad & 0.150 & 0.030 & $<0.001$ \\
\hline Frequency of remittances & 0.355 & 0.285 & 0.040 \\
\hline Number of visits to Moldova & 0.755 & 0.570 & $<0.001$ \\
\hline Contact with family and friends & 0.787 & 0.587 & $<0.001$ \\
\hline Index of socio-cultural integration & 0.381 & 0.580 & $<0.001$ \\
\hline Knowledge of the language of the destination country & 0.266 & 0.697 & $<0.001$ \\
\hline Time dedicated to certain activities & 0.360 & 0.430 & $<0.001$ \\
\hline Sources of information about the receiving society & 0.495 & 0.615 & $<0.001$ \\
\hline Index of economic integration & 0.703 & 0.612 & 0.003 \\
\hline Have a permanent contract & 0.803 & 0.773 & 0.424 \\
\hline Integration in the labour market & 0.700 & 0.553 & $<0.001$ \\
\hline Level of job satisfaction & 0.653 & 0.583 & 0.009 \\
\hline Age at arrival & 29.2 & 26.4 & 0.010 \\
\hline Number of years spent in CZ/IT & 5.3 & 12.8 & $<0.001$ \\
\hline Current age 50 or under [ref.] & $88.7 \%$ & $79.1 \%$ & 0.009 \\
\hline Over 50 & $11.3 \%$ & $20.9 \%$ & \\
\hline Females [ref.] & $47.3 \%$ & $63.9 \%$ & 0.001 \\
\hline Males & $52.7 \%$ & $36.9 \%$ & \\
\hline Without partners/children [ref.] & $28.7 \%$ & $31.6 \%$ & 0.005 \\
\hline Partners and children in CZ/IT & $47.0 \%$ & $57.3 \%$ & \\
\hline Partners and children in Moldova & $14.4 \%$ & $5.3 \%$ & \\
\hline Partners and children in CZ/IT and in Moldova & $9.9 \%$ & $5.8 \%$ & \\
\hline Primary education [ref.] & $17.8 \%$ & $6.8 \%$ & 0.004 \\
\hline Secondary education & $41.9 \%$ & $47.3 \%$ & \\
\hline University education & $40.3 \%$ & $45.9 \%$ & \\
\hline Salary up to 500 EUR [ref.] & $22.8 \%$ & $12.9 \%$ & $<0.001$ \\
\hline Salary 501-1000 EUR & $54.4 \%$ & $28.0 \%$ & \\
\hline Salary 1001-1500 EUR & $19.2 \%$ & $39.8 \%$ & \\
\hline Salary 1501 EUR+ & $3.6 \%$ & $19.4 \%$ & \\
\hline
\end{tabular}

Note: The p-value denotes the statistical significance of differences between respondents in Czechia and Italy and was calculated by two independent sample t-tests (continuous variables) and a chi-square test (age groups, gender, partner/children status, education, and gross salary), respectively. 
Table 4. Characteristics of respondents based on their cluster membership - first part

\begin{tabular}{|c|c|c|c|c|c|c|}
\hline & Cluster & $\mathrm{C} 1$ & $\mathrm{C} 2$ & C3 & $\mathrm{C} 4$ & C5 \\
\hline $\begin{array}{l}\text { Number of } \\
\text { respondents }\end{array}$ & & 103 & 70 & 72 & 62 & 102 \\
\hline \multirow{5}{*}{$\begin{array}{l}\text { Key } \\
\text { variables - } \\
\text { average values }\end{array}$} & $\begin{array}{l}\text { Number of previous } \\
\text { stays abroad }\end{array}$ & 0.49 & 0.30 & 0.17 & 0.13 & 0.20 \\
\hline & Frequency of remittances & 2.86 & 0.16 & 2.49 & 0.18 & 0.24 \\
\hline & $\begin{array}{l}\text { Number of visits to } \\
\text { Moldova }\end{array}$ & 3.45 & 3.77 & 2.17 & 2.35 & 1.59 \\
\hline & Contact with family & 2.94 & 2.79 & 2.38 & 1.06 & 2.74 \\
\hline & Contact with friends & 2.27 & 2.16 & 0.94 & 1.05 & 1.40 \\
\hline \multirow{5}{*}{$\begin{array}{l}\text { Explanatory } \\
\text { variables - } \\
\text { average values }\end{array}$} & Index of transnationality & 0.653 & 0.480 & 0.445 & 0.257 & 0.305 \\
\hline & $\begin{array}{l}\text { Index of socio-cultural } \\
\text { integration }\end{array}$ & 0.403 & 0.463 & 0.433 & 0.599 & 0.537 \\
\hline & $\begin{array}{l}\text { Index of economic inte- } \\
\text { gration }\end{array}$ & 0.690 & 0.636 & 0.656 & 0.611 & 0.668 \\
\hline & $\begin{array}{l}\text { Number of years spent } \\
\text { in IT/CZ }\end{array}$ & 7.4 & 7.8 & 10.3 & 11.5 & 9.5 \\
\hline & Age & 38.3 & 34.9 & 41.1 & 36.6 & 34.1 \\
\hline
\end{tabular}

dovan migration to Italy, represented by a larger and more strongly integrated community with a more homogeneous composition (e.g. more female carers in domestic and personal service; Drbohlav et al. [2017]), and higher salaries. Not surprisingly, the lower transnational index in Italy relates to the higher sociocultural integration of Moldovans in Italy (see the theoretical part above).

The transnational behaviour of migrants - a typology

The next step in the analysis was to select the most suitable clusters/types of transnational behaviour among Moldovans in Italy and Czechia. First, using five key variables (Table 4) to explain transnational activities, we identified five transnational clusters of migrants. We also added explanatory variables, which enabled us to better characterise particular clusters/types. Each variable in Table 4 indicates the average characteristics of the respondents. The last category of variables is composed of the percentage representation of selected 'other' variables. These indicators were intended to make it easier to understand what kind of migrants are represented in a given cluster/type. 
Table 4. Characteristics of respondents based on their cluster membership - second part

\begin{tabular}{llrrrrc}
\hline & Cluster & C1 & C2 & C3 & C4 & C5 \\
\hline 'Other' varia- & Czechia & $68.9 \%$ & $72.9 \%$ & $31.9 \%$ & $27.4 \%$ & $40.2 \%$ \\
bles - percen- & Females & $46.6 \%$ & $57.1 \%$ & $61.1 \%$ & $51.6 \%$ & $60.8 \%$ \\
& Education - Basic & $15.2 \%$ & $7.5 \%$ & $11.8 \%$ & $14.8 \%$ & $10.9 \%$ \\
& Education - Secondary & $40.4 \%$ & $43.3 \%$ & $45.6 \%$ & $54.1 \%$ & $43.6 \%$ \\
& Education - University & $44.4 \%$ & $49.3 \%$ & $42.6 \%$ & $31.1 \%$ & $45.5 \%$ \\
& Salary up to 500 EUR & $7.9 \%$ & $16.4 \%$ & $7.2 \%$ & $25.5 \%$ & $33.0 \%$ \\
& Salary 501-1000 EUR & $47.5 \%$ & $59.0 \%$ & $37.7 \%$ & $35.3 \%$ & $29.9 \%$ \\
& Salary 1001-1500 EUR & $35.6 \%$ & $18.0 \%$ & $40.6 \%$ & $25.5 \%$ & $23.7 \%$ \\
& Salary 1501 EUR+ & $8.9 \%$ & $6.6 \%$ & $14.5 \%$ & $13.7 \%$ & $13.4 \%$ \\
& Age group 18-25 & $14.7 \%$ & $27.5 \%$ & $2.8 \%$ & $32.3 \%$ & $27.5 \%$ \\
& Age group 26-35 & $32.4 \%$ & $34.8 \%$ & $27.8 \%$ & $22.6 \%$ & $36.3 \%$ \\
& Age group 36-45 & $24.5 \%$ & $15.9 \%$ & $36.1 \%$ & $14.5 \%$ & $18.6 \%$ \\
Age group 46+ & $28.4 \%$ & $21.7 \%$ & $33.3 \%$ & $30.6 \%$ & $17.6 \%$ \\
& Without partners/ & $20.4 \%$ & $31.4 \%$ & $14.1 \%$ & $43.5 \%$ & $42.2 \%$ \\
children & & & & & \\
Partners and children & $41.7 \%$ & $57.1 \%$ & $71.8 \%$ & $41.9 \%$ & $52.0 \%$ \\
in IT/CZ & & & & & \\
Partners and children & $24.3 \%$ & $4.3 \%$ & $9.9 \%$ & $3.2 \%$ & $2.9 \%$ \\
in Moldova & & & & & \\
Partners and children in & $13.6 \%$ & $7.1 \%$ & $4.2 \%$ & $11.3 \%$ & $2.9 \%$ \\
IT/CZ and in Moldova & & & & & \\
\hline
\end{tabular}

An analysis of variance confirmed the statistically significant differences in all the key variables presented in Table 4, with the exception of the economic integration index. A Chi-square test also proved that respondents assigned to all five clusters/types differed significantly by destination country, salary, age category, and partner status, but not by gender and education.

The distribution of the respondents across five clusters helps us to better understand the transnational behaviour of Moldovans, which we further described as transnational types. We identified the key difference between those who showed higher or lower degrees of transnationality. According to certain empirical surveys, it is clear that the greater the transnationality, the lower the (especially socio-cultural) integration [e.g. Snel, Engbersen and Leerkes 2006], and vice versa. Table 5 describes all of the types, together with their characteristics, including the different migratory behaviours of Moldovans living in Italy and Czechia. 
Table 5. Different types of transnational migrants: strong vs weak ties with country of origin

\begin{tabular}{|c|c|c|c|}
\hline & $\begin{array}{c}\text { Personal } \\
\text { characteristics }\end{array}$ & $\begin{array}{c}\text { Level of } \\
\text { integration - } \\
\text { socio-cultural } \\
\text { vs economic* }^{*}\end{array}$ & $\begin{array}{l}\text { Typical for } \\
\text { Moldovans in }\end{array}$ \\
\hline $\begin{array}{l}\text { Strong transnationality } \\
\text { with remittances [C1] }\end{array}$ & $\begin{array}{l}\text { Middle-aged } \\
\text { migrants, short } \\
\text { period of stay, less } \\
\text { educated }\end{array}$ & $-/+$ & Czechia \\
\hline $\begin{array}{l}\text { Strong transnationality } \\
\text { without remittances } \\
\text { [C2] }\end{array}$ & $\begin{array}{l}\text { Young immigrants, } \\
\text { short period of } \\
\text { stay, educated, } \\
\text { lower salary }\end{array}$ & $-/ 0$ & Czechia \\
\hline $\begin{array}{l}\text { Weak transnationality } \\
\text { with remittances [C } 3]\end{array}$ & $\begin{array}{l}\text { Older migrants, } \\
\text { longer period of } \\
\text { stay, higher salary }\end{array}$ & $-/ 0$ & Italy \\
\hline $\begin{array}{l}\text { Weak transnationality } \\
\text { [C4] }\end{array}$ & $\begin{array}{l}\text { Both young } \\
\text { and old, longer } \\
\text { period of stay, less } \\
\text { educated }\end{array}$ & $+/-$ & Italy \\
\hline $\begin{array}{l}\text { Weak transnationality } \\
\text { with contacts in } \\
\text { Moldova [C5] }\end{array}$ & $\begin{array}{l}\text { Young, families } \\
\text { or singles } \\
\text { in the country } \\
\text { of destination }\end{array}$ & $+/ 0$ & Italy/Czechia \\
\hline
\end{tabular}

Note: * Low [-], Moderate [0], High [+] socio-cultural vs economic level of integration.

While migrants who have strong contact with their home country predominated in Czechia, the Italian Moldovans maintained rather weak contact. Together with length of stay, this indicates a close relationship between the Italian Moldovans and their socio-cultural integration in the country of destination. The premises in the theoretical section assumed the opposite relation between transnationalism and integration, because highly socio-economically integrated immigrants tend to have fewer contacts with their country of origin than do those maintaining a low degree of integration.

Second, because we found differences in the behaviour of Moldovans living in Czechia and Italy, we examined the issue separately. Figure 1 shows the value of both key indices (of transnationalism and socio-cultural integration) vs cluster membership and destination country for each respondent.

The distribution of Moldovans in Italy is mostly located at the upper end of the integration axis, while the Moldovans in Czechia are located mostly at the upper end of the transnational axis. What does this mean in light of the concepts dis- 
Figure 1. Immigrants according to type of cluster, destination country, and indices of transnationality and socio-cultural integration

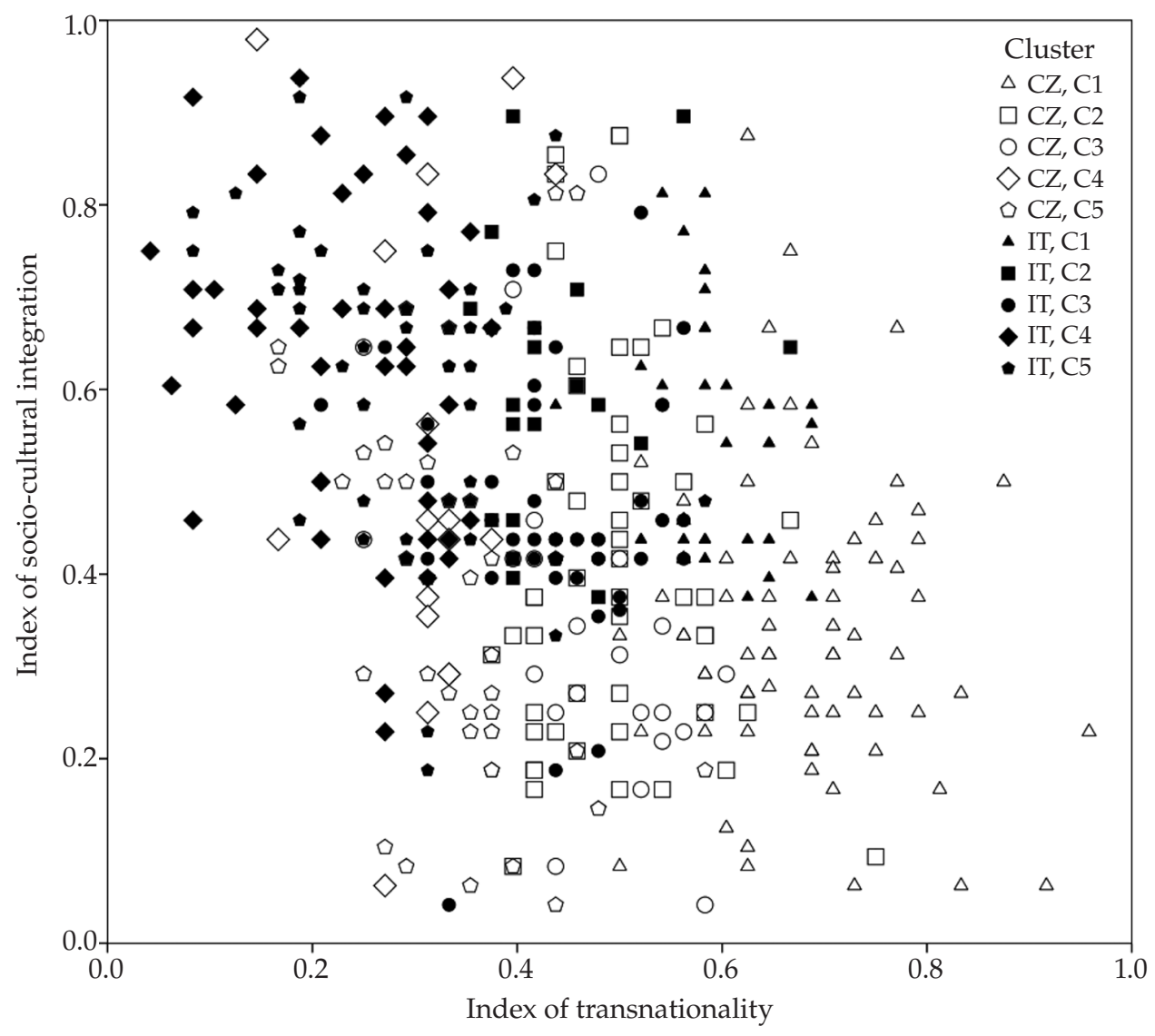

cussed? Even though cluster membership should not be taken in absolute terms, Figure 1 shows a clear distinction between the Moldovans in the two countries (in accordance with H1). Again, while the Italian Moldovans are more socio-culturally integrated into the majority society (clusters C3 and C4), the Czech Moldovans are more transnational (clusters $\mathrm{C} 1$ and $\mathrm{C} 2$ ) and (as already indicated in Table 3) also slightly more economically integrated than the Italian Moldovans. There are also many respondents concentrated at the centre of both axes from both destination countries that belong to type C5. These could be termed 'on the way to cluster $\mathrm{C}^{\prime}$ ', meaning that the respondents still had a significant attachment to their country of origin via contact with family members, but are already socio-culturally integrated. 


\section{How transnationalism influences the integration of immigrants}

The second hypothesis concerned the relationship between duration of residence, integration, and transnationalism. The assumption was that the transnational involvement and integration of migrants are mutually exclusive [Snel, Engbersen and Leerkes 2006]. However, there are also other potential development trajectories available, such as those demonstrated by degree of integration [e.g. Vertovec 2010] and empirical research [e.g. Itzigsohn and Saucedo 2002; Portes 2003]. In this section, we examine the relationship between transnational activities and the dimensions of integration.

\section{Transnational practices and socio-cultural integration}

First, we examined the relation between transnational practices and socio-cultural integration. This was done using three models (one for each country), to which we added step-by-step variables to predict socio-cultural integration. Table 6 presents the results of the regression analyses. The first models (CZ1, IT1) included only personal characteristics that were important for socio-cultural integration [see, e.g., Janská, Pauknerová and Koropecká 2017], such as the gender and family status of the respondents (i.e. whether a respondent was single or living with a partner/children, and where they lived). While the role of gender was not significant for either country, the respondents with partners did show a lower degree of integration (compared to the reference group of respondents without partners or children). Viewed at the country level, significantly less integration was found in Czechia for respondents who had part of their family in Czechia and another part in Moldova. This could include those who had left their children in their country of origin. In Italy, all of the respondents with partners/children were found to be less integrated. ${ }^{7}$ This may be because they lacked the time for cultural activities, as they needed to earn money and care for their families. The second models (CZ2, IT2) also included variables describing the migration backgrounds of the respondents (length of stay abroad, age upon arrival). Both were found to be significant; however, surprisingly, in the Czech context, it was clear that length of stay was more important for socio-cultural integration, while age upon arrival played a greater role in Italy. Moreover, the importance of family status diminished, meaning its effect in models CZ1 and IT1 was caused by the different migration backgrounds.

This finding is in accordance with traditional assimilation theories [e.g. Alba and Nee 1997], where integration into the mainstream is believed to increase

\footnotetext{
7 Surprisingly, those who had close relatives in Moldova appeared to be more highly integrated than those who had family in Italy. In view of the low proportion of migrants who had relatives in Moldova, however, this result cannot be taken as definitive.
} 
Table 6. Determinants of the level of socio-cultural integration among Moldovan immigrants in Czechia and Italy

\begin{tabular}{|c|c|c|c|c|c|c|c|}
\hline & & \multicolumn{3}{|c|}{ Czechia } & \multicolumn{3}{|c|}{ Italy } \\
\hline \multicolumn{2}{|c|}{ Model } & CZ1 & CZ2 & CZ3 & IT1 & IT2 & IT3 \\
\hline \multirow[t]{4}{*}{1} & Sex [male] & -0.028 & 0.042 & 0.054 & -0.056 & -0.056 & -0.064 \\
\hline & $\begin{array}{l}\text { Partner/children } \\
\text { only in CZ/IT }\end{array}$ & -0.016 & -0.079 & -0.082 & $-0.425^{* * *}$ & $*-190^{* *}$ & -0.137 \\
\hline & $\begin{array}{l}\text { Partner/children } \\
\text { only in Moldova }\end{array}$ & $-0.145^{*}$ & -0.073 & -0.039 & $-0.287^{* * *}$ & * -0.032 & 0.010 \\
\hline & $\begin{array}{l}\text { Partner/children } \\
\text { in Moldova and } \\
\text { CZ/IT }\end{array}$ & $-0.193^{* *}$ & $-0.149^{*}$ & -0.130 & $-0.236^{* * *}$ & * -0.015 & 0.007 \\
\hline \multirow[t]{2}{*}{2} & $\begin{array}{l}\text { Length of stay } \\
\text { abroad }[\mathrm{CZ} / \mathrm{IT}]\end{array}$ & & $0.346^{* * *}$ & $0.320^{* * *}$ & & $0.114^{*}$ & $0.112^{*}$ \\
\hline & Age at arrival & & $-0.160^{* *}$ & $-0.161^{* *}$ & & $-0.479^{* * *}$ & $-0.463^{* * *}$ \\
\hline \multirow[t]{2}{*}{3} & $\begin{array}{l}\text { Index of trans- } \\
\text { nationalisation }\end{array}$ & & & $-0.126^{*}$ & & & $-0.126^{*}$ \\
\hline & $\mathrm{R}^{2}$ & 4.8 & 17.7 & 19.0 & 18.5 & 31.6 & 32.7 \\
\hline
\end{tabular}

Note: ${ }^{*} \mathrm{p}<0.10 ;{ }^{* *} \mathrm{p}<0.05 ;{ }^{* * *} \mathrm{p}<0.01$; the table presents the standardised regression coefficients.

with the length of stay in the destination country. Age upon arrival also plays an important role, with those arriving in the destination country at a young age being more integrated [e.g. Snel, Engbersen and Leerkes 2006], and vice versa. These results indicate that the degree of integration clearly increases with the length of stay and age upon arrival, which still held when we added the key variable of index of transnationalisation (models CZ3, IT3). It can be concluded that the more transnational migrants are, the less likely they are to be socio-culturally integrated, as has been well described in the literature [e.g. ibid.].

\section{Transnational practices and economic integration}

An important part of the integration process is represented by economic activity. We were interested in how such activity could be influenced by transnational practices and in the importance of these practices when comparing transnational practices with socio-cultural integration. The same logic applied to the previous regression analysis (Table 7) provided different results for the variables. Unambiguously, the main predictor of economic integration was gender. The emergence of transnationalism parallels successful economic integration in the Ital- 
Table 7. Determinants of the level of economic integration among Moldovan immigrants in Czechia and Italy

\begin{tabular}{|c|c|c|c|c|c|c|c|}
\hline \multirow{2}{*}{ Model } & \multirow[b]{2}{*}{ Variables } & \multicolumn{3}{|c|}{ Czechia } & \multicolumn{3}{|c|}{ Italy } \\
\hline & & CZ4 & CZ5 & CZ6 & IT4 & IT5 & IT6 \\
\hline \multirow[t]{4}{*}{1} & Sex [male] & $0.142^{*}$ & $0.162^{*}$ & $0.166^{*}$ & $0.265^{* * *}$ & $0.254^{* * *}$ & $0.265^{* * *}$ \\
\hline & $\begin{array}{l}\text { Partner/children } \\
\text { only in CZ/IT }\end{array}$ & 0.061 & 0.048 & 0.046 & 0.040 & 0.106 & 0.056 \\
\hline & $\begin{array}{l}\text { Partner/children } \\
\text { only in Moldova }\end{array}$ & -0.009 & 0.049 & 0.061 & -0.006 & 0.049 & 0.005 \\
\hline & $\begin{array}{l}\text { Partner/children } \\
\text { in Moldova and } \\
\mathrm{CZ} / \mathrm{IT}\end{array}$ & -0.028 & 0.014 & 0.020 & 0.048 & 0.101 & 0.082 \\
\hline \multirow[t]{2}{*}{2} & $\begin{array}{l}\text { Length of stay } \\
\text { abroad }[\mathrm{CZ} / \mathrm{IT}]\end{array}$ & & $0.158^{*}$ & $0.147^{*}$ & & -0.063 & -0.068 \\
\hline & Age at arrival & & -0.113 & -0.114 & & -0.083 & -0.106 \\
\hline \multirow[t]{2}{*}{3} & $\begin{array}{l}\text { Index of trans- } \\
\text { nationalisation }\end{array}$ & & & -0.049 & & & 0.136 \\
\hline & $\mathrm{R}^{2}$ & 2.7 & 6.0 & 6.2 & 7.3 & 7.8 & 9.2 \\
\hline
\end{tabular}

Note: ${ }^{*} p<0.10 ;{ }^{* *} p<0.05 ;{ }^{* * *} p<0.01$; the table presents the standardised regression coefficients.

ian case, with an increase in transnational practices being slightly related to the process of economic (and social) mobility [Itzigsohn and Saucedo 2002; Fibbi and D'Amato 2008].

The analyses include such economic indicators as size of contract, professional qualifications for their current occupation, and satisfaction with their employment. One of the explanations for why men were more economically integrated than women was that men usually have better access to suitable employment than women [e.g. Erdal 2013]. In Czechia, the length of stay in the destination country also played a significant role. From previous studies on Ukrainian labour migrants [e.g. Drbohlav 2015], it was determined that the length of stay in Czechia correlated with having more information about labour market opportunities. We expected a similar situation for Moldovans, who also occupy the post-Soviet space and face similar restrictions to entry into EU labour markets.

Interestingly, both analyses indicated that the degree of transnational practices could have different impacts on particular aspects of integration, with a negative impact being exerted on the socio-economic dimension of integration and a slightly positive impact on the economic dimension. This result led us to question the potential for a zero-sum relationship between transnationalism and integration [e.g. King and Collyer 2016 vs Portes, Haller and Guarnizo 2002]. 


\section{Conclusion and discussion: integration patterns from a transnational perspective}

The aim of this study was to discover whether transnational migrants have been able to integrate well into their receiving societies and to explore the potential differences in the migratory behaviours of Moldovans in two EU countries with very different migration histories and contexts. We assumed that there would be differences between the two countries reflecting the degree of language distance and involvement in the labour market. We also tried to determine whether there were differences in the migratory patterns between an established and a relatively new EU country.

Many studies on transnationalism have either been theoretical or based on qualitative empirical data, with quantitative work being limited [e.g. Snel et al. 2006; Engbersen et al. 2013]. Here, we offered a unique quantitative examination of the transnational and integration activities of Moldovans in two countries at the same time. To test our premises, we conducted an empirical survey among Moldovan labour migrants in Czechia and Italy. With respect to our hypothesis $\mathrm{H} 1$, we did find important differences between Moldovans living in Italy and Czechia. We constructed a typology of the transnational activities of Moldovan migrants based on variables connected to transnational behaviours. The results showed that five clusters/types (C1-C5) were distinguishable, with strong transnational networks (connected to weak socio-cultural integration) being typical mostly for Moldovans in Czechia, while weak integration was also observed. On the other hand, Moldovans in Italy reported weak transnational ties and, at the same, time greater socio-cultural integration. One reason for these outcomes may be the existence of the Integration Plan in Italy, which promotes pre-departure training courses to prompt people in selected countries of origin to favour Italy as a destination [Caneva 2014]. This means that Moldovans who have attended training programmes and language courses at home are allowed privileged entry into Italy, within preferential quotas, which is not the case for Czechia.

A more interesting result is cluster C5, where transnationalism is linked to integration via relationships (visits) in Moldova. This type was not defined in terms of a particular country of destination, meaning that those migrants could be elsewhere. At the same time, it was found that transnational activities were evident among migrants with a good social position (e.g. education level, labour market participation) in the host society and those who were more marginalised [Snel, Engbersen and Leerkes 2006; Engbersen et al. 2013].

Hypothesis $\mathrm{H} 2$ concerned the integration of transnational migrants, and we tested how these networks varied by duration of residence, age upon arrival, relations with family, etc. Those who had frequent contact with their home country (e.g. travelled home) and a shorter period of residence were more likely to exhibit less integration than those who had almost no contact and had lived longer in the receiving country.

The analyses yielded results that, on the one hand, confirmed this hypoth- 
esis and, on the other hand, did not. We analysed the degree of integration of the respondents via the transnational variables. It is clear that transnationalism had a negative impact on socio-cultural integration, while age at time of arrival and subsequent length of stay in the destination country also had a significant impact. However, the difference was not significant between Italy and Czechia. At the same time, transnationalism had a very slight positive impact on economic integration, which supports a close relationship between economic integration and economic transnational ties [e.g. Vertovec 2010] in Italy, but not in Czechia, where length of stay and family status played more important roles. Moreover, the much better economic integration of men compared to women was confirmed in both countries.

This work has explored this balancing act. It went beyond simply acknowledging the co-existence of transnationalism and processes of integration to propose a typology for understanding the nature of the interaction between the two. We argue that the nature of interactions/networks between integration and transnationalism are formed by the fact that the two are both constituents of a social process, and that the nature of interactions is further shaped by the human and personal considerations of the key actors - the migrants and those with whom they interact. Although, generally speaking, transnational involvement does not constitute an impediment to successful integration into majority societies, the situation for specific countries and specific groups of immigrants may actually be quite different. Moreover, our results showed that it is important to distinguish between particular dimensions of integration (socio-cultural, economic, etc.) and relevant variables such as length of stay, gender, knowledge of the language, remittances, or ties among migrants, their families, and friends. Economic integration thus does not have to be weaken with transnational behaviour of migrants, while socio-cultural integration does [see Vertovec 2010; Portes et al. 2002].

Our results contribute some new insights to the scholarly discussion on how the transnational migratory behaviour of migrants influences their integration process, and what factors play a role in this. Moreover, it broadens the literature on East European migrants in the EU labour market.

EVA JANSKÁ is an associate professor of social and regional geography at the Faculty of Sceince, Charles University in Prague. ORCID: 0000-0003-3451-2832.

JIŘí HASMAN is an assistant professor in geography at the Faculty of Science, Charles University in Prague. ORCID: 0000-0002-1929-4833

ZDENĚK ČERMÁK is an associate professor of social and regional geography at the Faculty of Science, Charles University in Prague. ORCID: 0000-0001-7230-8571 


\section{References}

Alba, R. and V. Nee. 1997. ‘Rethinking Assimilation Theory for a New Era of Immigration.' International Migration Review 31 (4): 826-874, https://doi.org/10.1177/019791839703100403.

Baldassar, L. and L. Merla. 2014. 'Introduction: Transnational Family Caregiving Through the Lens of Circulation.' Pp. 3-24 in Transnational Family Caregiving Through the Lens of Circulation: Understanding Mobility and Absence in Family Life, edited by L. Baldassar and L. Merla. London: Routledge.

Basch, L., N. Glick Schiller and C. Szanton Blanc. 1994. Nations Unbound: Transnational Projects, Postcolonial Predicaments, and Deterritorialized Nation-States. London: Routledge.

Caneva, E. 2014. 'The Integration of Migrants in Italy: An Overview of Policy Instruments and Actors.' INTERACTRR2014/05, Robert Schuman Centre for Advanced Studies, San Domenico di Fiesole [FI]: European University Institute. Retrieved 12 November 2018 (http://cadmus.eui.eu/bitstream/handle/1814/32019/INTERACT-RR-2014_05.pdf).

Cela, E., T. Fokkema and E. Ambrosetti. 2013. 'Variation in Transnationalism among Eastern European Migrants in Italy: The Role of Duration of Residence and Integration.' Southeast European and Black Sea Studies 13 (2): 195-209, https://doi.org/10.1080/14683857.2013.789671.

Cingolani, P. and F. Vietti. 2019. 'Social Remittances and Local Development in the Republic of Moldova. A Critical Analysis of Migrants as Agents of Change.' Southeast European and Black Sea Studies 19 (4): 625-641, https://doi.org/10.1080/14683857.2019.1657685.

Constant, A. and D. S. Massey. 2002. ‘Return Migration by German Guestworkers: Neoclassical versus New Economic Theories.' International Migration 40 (4): 5-38, https://doi.org/10.1111/1468-2435.00204.

Dahinden, J. 2010. “"The Dynamics of Migrants” Transnational Formations: Between Mobility and Locality.' Pp. 51-57 in Diaspora and Transnationalism: Concepts, Theories and Methods, edited by R. Bauböck and T. Faist. Amsterdam: Amsterdam University Press.

David, M. and D. Sutton. 2004. Social Research: The Basics. London: Sage.

Drbohlav, D., A. Bailey, Z. Čermák, D. Čermáková, D. Lozovanu, E. Masná, L. Pavelková, et al. 2017. 'Diversification Trends in Moldovan International Migration: Evidence from Czechia and Italy.' AUC Geographica 52 (2): 237-248, https://doi.org/10.14712/23361980.2017.19.

Drbohlav, D. 2015. Ukrajinská pracovní migrace v Česku: Migrace - Remitence - (Rozvoj). (Ukrainian labour migration in the Czech Republic: migration - remittances (development) Prague: Karolinum.

Düvell, F. and D. Vogel. 2006. 'Polish Migrants: Tensions between Sociological Typologies and State Categories.' Pp. 267-289 in Contemporary Polish Migration in Europe. Complex Patterns of Movement and Settlement, edited by A. Triandafyllidou. Lewiston, NY: Edwin Mellen Press.

Dustmann, C. 1996. 'Return Migration - the European Experience.' Economic Policy: A European Forum 22: S215-249, https://doi.org/10.2307/1344525.

Eade, J., S. Drinkwater and M. P. Garapich. 2006. 'Class and Ethnicity: Polish Migrant Workers in London.' End of Award Report No. RES- 000-22-1294. Swindon: Economic and Social Research Council. Retrieved 5 December 2018 (https://www.surrey.ac.uk/ cronem/files/POLISH_FINAL_RESEARCH_REPORT_WEB.pdf). 
Engbersen, G., A. Leerkes, I. Grabowska-Lusinska, E. Snel and J. Burgers. 2013.

'A Typology of Labour Migration on the Differential Attachments of Migrants from Central and Eastern Europe.' Journal of Ethnic and Migration Studies 39 (6): 959-981, https://doi.org/10.1080/1369183X.2013.765663.

Entzinger, H. and R. Biezefeld. 2003. Benchmarking in Immigrant Integration. Rotterdam: Ercomer.

Erdal, M. B. 2013. 'Migrant Transnationalism and Multi-Layered Integration: NorwegianPakistani Migrants' Own Reflections.' Journal of Ethnic and Migration Studies 39 (6): 983-999, https://doi.org/10.1080/1369183X.2013.765665.

Faist, T. 2000. The Volume and Dynamics of International Migration and Transnational Social Spaces. Oxford: Oxford University Press, https://doi.org/10.1093/acprof:oso/9780198293910.001.0001.

Fibbi, R. and G. D'Amato. 2008. 'Transnationalism of Migrants in Europe: Empirical Evidence.' [In French.] Revue Européenne des Migrations Internationales 24 (2): 7-22, https://doi.org/10.4000/remi.4452.

Fokkema, T., L. Lessard-Phillips, J. D. Bachmeier and S. K. Brown. 2012. 'The Link between the Transnational Behaviour and Integration of the Second Generation in European and American Cities: Does the Context of Reception Matter?' Nordic Journal of Migration Research 2 (2): 111-123, https:// doi.org/10.2478/v10202-011-0033-x.

Glick-Schiller, N., L. Basch and C. S. Blanc. 1992. Towards a Transnational Perspective on Migration: Race, Class, Ethnicity, and Nationalism Reconsidered. New York: New York Academy of Sciences.

Gordon, M. 1964. Assimilation in American Life: The Role of Race, Religion and National Origins. New York: Oxford University Press.

Grabowska-Lusinska, I. and M. Okólski. 2009. Emigracja Ostatnia? Warsaw: Wydawnictwo Naukowe Scholar.

Guarnizo, L. E., A. Portes and W. Haller. 2003. 'Assimilation and Transnationalism: Determinants of Transnational Political Action among Contemporary Migrants.' American Journal of Sociology 108 (6): 1211-1248, https://doi.org/10.1086/375195.

Itzigsohn, J., C. Dore Cabral, E. Hernandez Medina and O. Vazquez. 1999. ‘Mapping Dominican Transnationalism: Narrow and Broad Transnational Practices.' Ethnic and Racial Studies 22 (2): 316-339, https://doi.org/10.1080/014198799329503.

Itzigsohn, J. and S. G. Saucedo. 2002. 'Immigrant Incorporation and Sociocultural Transnationalism.' International Migration Review 36 (3): 766-798, https://doi.org/10.1111/j.1747-7379.2002.tb00104.x.

Janská, E., K. Pauknerová and M. Koropecká. 2017. 'Transnational Behaviour of Ukrainian Remitting Migrants.' Tijdschrift voor economische en sociale geografie 108 (5): 656-668, https://doi.org/10.1111/tesg.12243.

King, R. and M. Collyer. 2016. 'Migration and Development Framework and Its Links to Integration.' Pp. 167-188 in Integration Processes and Policies in Europe, edited by B. Garcés-Mascareňas and R. Penninx. Cham: Springer.

Kivisto, P. 2001. 'Theorizing Transnational Immigration: A Critical Review of Current Efforts.' Ethnic and Racial Studies 24 (4): 549-577, https://doi.org/10.1080/01419870120049789.

Kushnirovich, N. 2015. 'Economic Integration of Immigrant Entrepreneurs.' Entrepreneurial Business and Economics Review 3: 9-27, https://doi.org/10.15678/EBER.2015.030302.

Levitt, P. 2001. The Transnational Villagers. Berkeley, CA: University of California Press, https://doi.org/10.1525/9780520926707.

Morad, M. and F. Della Puppa. 2019. 'Bangladeshi Migrant Associations in Italy: Transnational Engagement, Community Formation and Regional Unity.' Ethnic and Racial Studies 42 (10): 1788-1807, https://doi.org/10.1080/01419870.2018.1515441. 
Morawska, E. 2003. 'Immigrant Transnationalism and Assimilation: A Variety of Combinations and the Analytic Strategy it Suggests.' Pp. 133-176 in Toward Assimilation and Citizenship: Immigrants in Liberal Nation-States, edited by C. Joppke and E. Morawska. Basingstoke: Palgrave Macmillan, https://doi.org/10.1057/9780230554795_6.

Mosneaga, V. 2012. 'Moldovan Labour Migrants in the European Union: Problems of Integration.' CARIM-East RR 2012/41, Robert Schuman Centre for Advanced Studies, San Domenico di Fiesole [FI]: European University Institute. Retrieved 5 November 2018 (http://www.carim-east.eu/media/CARIM-East-2012-RR-41.pdf).

Penninx, R. and B. Garcés-Mascareñas. 2016. Integration Processes and Policies in Europe. Cham: Springer, https://doi.org/10.1007/978-3-319-21674-4.

Portes, A. 1997. 'Immigration Theory for a New Century: Some Problems and Opportunities.' International Migration Review 31 (4): 799-825, https://doi.org/10.1177/019791839703100402.

Portes, A. 2003. 'Conclusion: Theoretical Convergencies and Empirical Evidence in the Study of Immigrant Transnationalism.' International Migration Review 37 (3): 874-892, https://doi.org/10.1111/j.1747-7379.2003.tb00161.x.

Portes, A., L. Guarnizo and P. Landolt. 1999. 'The Study of Transnationalism: Pitfalls and Promise of an Emergent Research Field.' Ethnic and Racial Studies 22 (2): 217-237, https://doi.org/10.1080/014198799329468.

Portes, A., W. J. Haller and L. E. Guarnizo. 2002. 'Transnational Entrepreneurs: An Alternative Form of Immigrant Economic Adaptation.' American Sociological Review 67 (2): 278-298, https://doi.org/10.2307/3088896.

Portes, A. and R. G. Rumbaut. 1996. Immigrant America. Berkeley, CA: University of California Press.

Portes, A. and M. Zhou. 1999. 'Entrepreneurship and Economic Progress in the 1990s: A Comparative Analysis of Immigrants and African Americans.' Pp. 143-171 in Immigration and Opportunity: Race, Ethnicity, and Employment in the United States, edited by F. D. Bean and S. Bell-Rose. New York: Russell Sage Foundation.

Sana, M. 2005. 'Buying Membership in the Transnational Community: Migrant Remittances, Social Status, and Assimilation.' Population Research and Policy Review 24 (3): 231-261, https://doi.org/10.1007/s11113-005-4080-7.

Snel, E., G. Engbersen and A. Leerkes. 2006. 'Transnational Involvement and Social Integration.' Global Networks 6 (3): 285-308, https://doi.org/10.1111/j.1471-0374.2006.00145.x.

Trevena, P. 2013. 'Why Do Highly Educated Migrants Go for Low-Skilled Jobs? A Case Study of Polish Graduates Working in London.' Pp. 169-190 in Mobility in Transition: Migration Patterns after EU Enlargement, edited by B. Glorius, I. Grabowska-Lusinska and A. Kuvik. Amsterdam: Amsterdam University Press, https://doi.org/10.1515/9789048515493-009.

United Nations. 2015. International Migrant Stock 2015. Retrieved 15 January 2016 (https://www.un.org/en/development/desa/population/migration/data/ estimates2/estimates15.asp).

Van Dalen, H. P., G. Groenewold and T. Fokkema. 2005. 'The Effect of Remittances on Emigration Intentions in Egypt, Morocco, and Turkey.' Population Studies 59 (3): 375-392, https://doi.org/10.1080/00324720500249448.

Vertovec, S. 1999. 'Conceiving and Researching Transnationalism.' Ethnic and Racial Studies 22 (2): 447-462, https://doi.org/10.1080/014198799329558.

Vertovec, S. 2007. 'Introduction: New Dimensions in the Anthropology of Migration and Multiculturalism.' Ethnic and Racial Studies 30 (6): 961-978, https://doi.org/10.1080/01419870701599416. 
Vertovec, S. 2010. Transnationalism. Abingdon: Routledge, https://doi.org/10.4324/9780203927083.

World Bank. 2018. World Bank Database. Retrieved 11 November 2018 (https://data.worldbank.org/indicator/bx.trf.pwkr.dt.gd.zs?year_high_desc=false). de Zwager, N. and R. Sintov. 2014. 'Driving Innovation in Circular Migration: Migration and Development in Moldova: Market Analysis. Chisinau.' Moldova: NEXUS. Retrieved 11 December 2018 (http:// civis.md/Archive/IASCI-CIVIS Migration + Development in Moldova - Market Analysis 2014.pdf). 